Jurnal ENGINE Vol.1 No.1, Mei 2017, pp 11-19

e-ISSN: 2579-7433

\title{
PENGARUH PERUBAHAN DIAMETER LUBANG SALURAN KELUAR JETMAIN DARI 2,5 MM MENJADI 2,8 MM PADA KARBURATOR TERHADAP KINERJA MESIN BENSINEMPAT LANGKAH SATU SILINDER PADA SEPEDA MOTOR
}

\author{
${ }^{1)}$ Wardoyo, ${ }^{2)}$ Andi Putro Sukendro \\ ${ }^{1,2)}$ Prodi Teknik Mesin Universitas Proklamasi 45 Yogyakarta \\ 1)e-mail: Ward_up45@yahoo.com \\ Jl. Proklamasi No. 1 Babarsari Yogyakarta
}

\begin{abstract}
This study aimed to compare the influence of the hole diameter of the outlet of the main jet from $2.5 \mathrm{~mm}$ to $2.8 \mathrm{~mm}$ on the carburetor to the engine performance and fuel consumption. The test is performed with the brand gasoline motor honda tiger type GL $200 R$ four-stroke single cylinder. The materials studied were the main jet. Tests performed with standard conditions in without making any changes. Testing machine at the ready on a dynamometers test bed. Then do the testing phase and retrieval of data that is torque and fuel consumption. Torque $(\mathrm{Nm})$ play a modified jet yield increase of $2.2 \%$ from the main jet standard. Power $(\mathrm{kW})$ jet modification produces a maximum power of around $2.2 \%$ of the main jet standard. The rate of fuel consumption ( $m f$ ) on the main jet modification is greater than the main jet standard. Fuel consumption ( $s f c$ ) on the main jet modification will further increase the standard of the main jet. Calorific fuel (Qi) in the main jet modification is greater than the main jet standard. Jet played modifications that do not significantly change the main jet standard.
\end{abstract}

Keywords: Main Jet, Fuel, Power.

\section{PENDAHULUAN}

Perkembangan teknologi otomotif yang pesat saat ini berdampak terhadap majunya alat transportasi, terutama sepeda motor. Sepeda motor adalah salah satu wujud barang sebagai alat transportasi darat yang dominan saat ini serta menjanjikan kemudahan bagi para penggunanya. Sepeda motor saat ini masih bergantung pada jenis bahan bakar yang digunakannya. Penelitian ini kajiannya adalah pengaruh perubahan diameter lubang saluran keluar Jet Main dari 2,5 $\mathrm{mm}$ menjadi $2,8 \mathrm{~mm}$ pada karburator terhadap kinerja mesin bensin 4 langkah 1 silinder untuk sepeda motor. Penelitian ini merupakan suatu rekayasa terhadap perkembangan teknologi di bidang otomotif karena banyaknya pengguna kendaraan bermotor yang merasa kurang puas terhadap performance kendaraan standard dari pabrik serta untuk memperkecil dampak-dampak yang kurang baik terhadap lingkungan akibat dari emisi gas buang yang ditimbulkan.

\section{METODE PENELITIAN}

Pengujian ini dilakukan dengan menggunakan motor bensin merk honda tiger type GL200R4 Langkah 1 silinder, di titik beratkan pada unjuk kerja mesin.

Pada saat pengujian ini tentunya menemui berbagai kendala yang dikarenakan keterbatasan beberapa faktor penunjang sehingga mempengaruhi keakuratan hasil penelitian yang diantaranya kondisi mesin uji dan alat-alat ukur yang digunakan. Penelitian dilakukan di Yogyakarta. Dalam penelitian ini sistem pengambilan data dilakukan berdasarkan percobaan, sehingga dalam pengambilan data didasarkan pada urutan kerja mesin tersebut.

\section{A. Bahan Penelitian}

Bahan yang diteliti adalah Jet Main. Jet Main berfungsi untuk menyuplai kebutuhan bahan bakar yang sesuai pada semua tingkat kecepatan mesin putaran tinggi. Hal ini dimungkinkan oleh perubahan posisi piston valve. Semakin 
Jurnal ENGINE Vol.1 No.1, Mei 2017, pp 11-19 e-ISSN: 2579-7433

tinggi posisi piston valve, maka semakin tinggi jarum skep terangkat, karena bentuk jarum yang tirus, maka semakin besar celah bakar yang akan keluar dari ruang bahan bakar. Berikut ini gambar Jet Main yang diteliti.

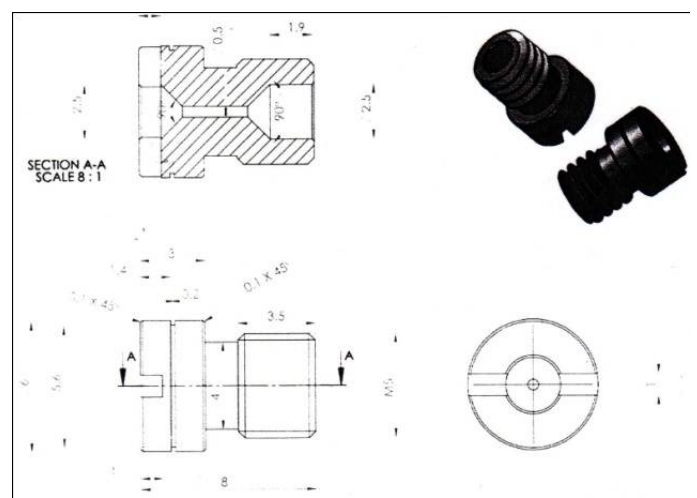

Gambar 1. Bentuk Alat Jet Main 2,5 mm atau standard

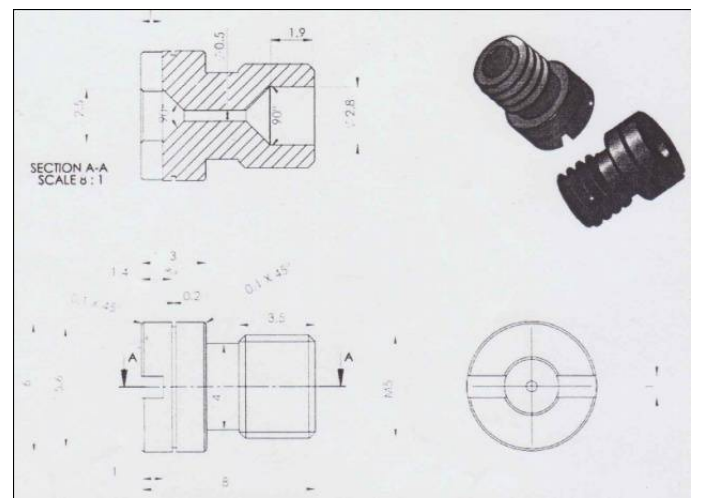

Gambar 2. Bentuk Alat Jet Main 2,8 mm atau modifikasi

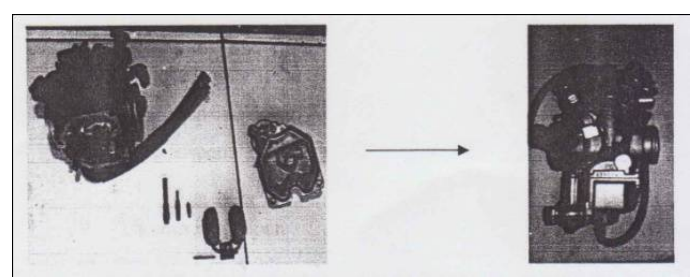

Gambar 3. Karburator Merk Honda Tiger type GL 200 R

\section{B. Alat Penelitian}

Alat yang dipakai untuk penelitian adalah Honda Tiger type GL 200 R

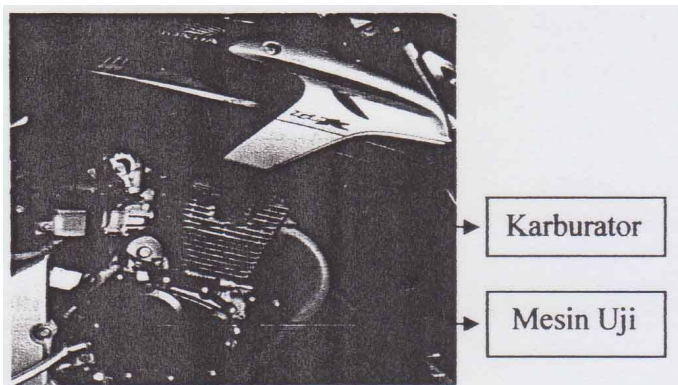

Gambar 4. Mesin Uji Merk Honda Tiger type GL 200 R

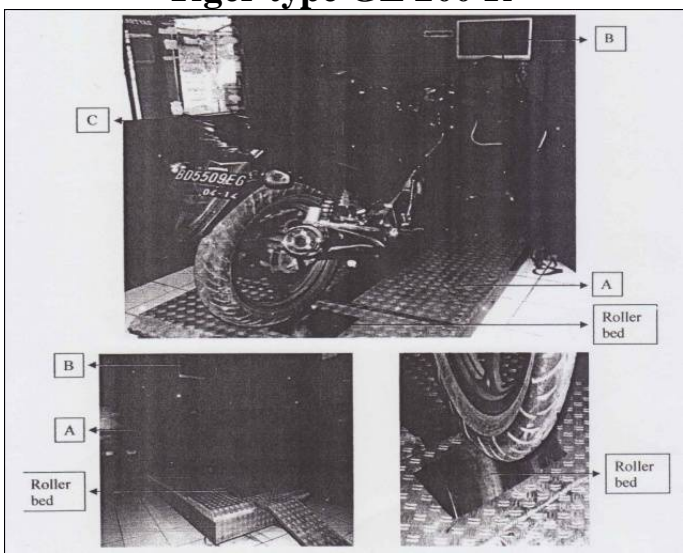

Gambar 5. Instalasi Alat Penelitian

Keterangan gambar:

A. Dynamometer: untuk mengukur torsi mesin

B. Tachometer: untuk mengukur putaran mesin

C. Buret ukur: untuk mengukur konsumsi bahan bakar

\section{Cara Penelitian}

Dalam pengujian ini dilakukan dengan mesin kondisi standar sesuai dengan pabrik pembuatnya tanpa melakukan perubahan apapun. Penelitian dilaksanakan 2 tahap.

\section{1) Tahap Persiapan}

Tahap persiapan dimaksudkan untuk membantu keakuratan pengambilan data pada tahap pengujian serta kesadaran akan faktor-faktor keselamatan kerja yang mutlak untuk diperhatikan pada tahap pengujian.

a. Melakukan service tune up pada mesin yang akan digunakan untuk pengujian meliputi ganti oli mesin, pengecekan busi, penyetelan 
Jurnal ENGINE Vol.1 No.1, Mei 2017, pp 11-19

e-ISSN: 2579-7433

karburator, kerenggangan katup, waktu pengapian sesuai dengan standard pabrik pembuatnya dan pembersihan pada saluran buang.

b. Mengecek soket-soket dan kabelkabel pengapian pada CDI, koil, motor stater, accu dan massa terangkai dengan benar pada mesin uji.

c. Mempersiapkan alat yang akan diuji meliputi:

- Jet Main yang digunakan adalah lubang saluran keluar 2,5 mm

- Jet Main yang digunakan adalah lubang saluran keluar 2,8 $\mathrm{mm}$

d. Pemasangan dan penyetelan mesin uji pada tes bed dynamometer, pemasangan saluran (slang bahan bakar) pada buret ukur ke karburator dan memastikan dapat bekerja dengan baik.

e. Menyiapkan alat bantu lainnya seperti tachometer dan stopwatch serta mengesetnya agar dapat bekerja dengan baik.

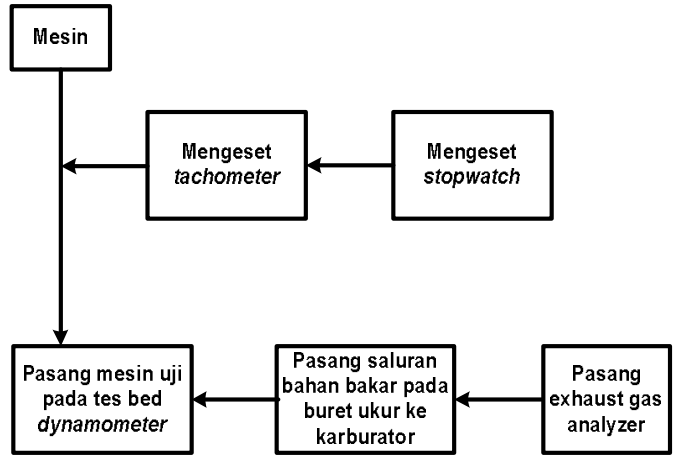

\section{Tahap pengujian}

Setelah memeriksa alat pengujian selesai kemudian dilakukan tahap pengujian. Langkah-langkah pengujian adalah sebagai berikut:

a. Mesin kondisi standard (diameter Jet Main 2,5 mm). Pengisian bahan bakar pada tangki bahan bakar buret ukur, buka kran sampai menunjukkan $25 \mathrm{ml}$ pada buret ukur, kemudian tutup kembali kran tersebut.

b. Hidupkan mesin uji, setel putaran mesin pada putaran stationer dan pemanasan mesin dalam keadaan normal, yaitu dimaksudkan untuk

mencapai kondisi operasi mesin sebenarnya. Selain itu untuk memastikan mesin sudah bekerja dengan maksimal dengan bahan bakar mesin yang diinginkan. Pemanasan dilakukan kira-kira 3-5 menit.

a. Setelah tahap pemanasan selesai, gigi persneling dimasukkan pada gigi persneling ke-3, dimaksudkan agar putaran dan torsi yang dihasilkan sama dengan putaran poros mesin uji.

c. Mengatur putaran mesin dengan memutar grip gas hingga mencapai putaran $6000 \mathrm{rpm}$, setelah putaran yang diinginkan sudah tercapai, mulai pengambilan data yaitu torsi pada dynamometer. Waktu konsumsi bahan bakar tiap $2 \mathrm{ml}$ bahan bakar dan kandungan emisi gas buang.

d. Menaikkan putaran mesin setiap kenaikan $500 \mathrm{rpm}, 1000 \mathrm{rpm}$ dan mencatat data torsi pada dynamometer. Waktu konsumsi bahan bakar sampai putaran $6000 \mathrm{rpm}$ dengan memutar grip gas.

e. Mencatat data operasi meliputi putaran mesin, torsi yang dihasilkan serta waktu untuk menghabiskan $2 \mathrm{ml}$ bahan bakar. Pada setiap rpm dilakukan tiga kali pengambilan data.

f. Setelah mencapai putaran $6000 \mathrm{rpm}$ dan pencatatan data selesai, maka putaran mesin sedikit demi sedikit dikurangi dan mematikan mesin setelah mencapai putaran stationer.

g. Pengujian dengan kondisi Jet Main yang di modifikasi (diameter 2,8 mm). Pengujian dilakukan dengan cara yang sama dengan mesin kondisi standar. Mesin dijalankan dan diamati putaran torsi, pemakaian bahan bakar. Prosesnya sama seperti pada mesin kondisi standard.

\section{HASIL DAN PEMBAHASAN}

\section{A. HASIL}


Jurnal ENGINE Vol.1 No.1, Mei 2017, pp 11-19

e-ISSN: 2579-7433

Proses pengujian operasi mesin dilakukan pada putaran $2000 \mathrm{rpm}$ sampai dengan putaran $6000 \mathrm{rpm}$.

Data hasil pengujian yang telah dilakukan didapatkan data-data sebagai berikut:

Tabel 1. Hasil Pengujian Pemakaian Jet Main Standard (2,5 mm).

\begin{tabular}{|c|c|c|}
\hline Putaran mesin (rpm) & Torsi (NM) & $\begin{array}{c}\text { Konsumsi bahan bakar/waktu } \\
(\mathrm{ml} / \mathrm{s})\end{array}$ \\
\hline 2000 & 15,80 & 0,1269 \\
\hline 2500 & 15,86 & 0,1306 \\
\hline 3000 & 15,92 & 0,1664 \\
\hline 4000 & 16,09 & 0,1968 \\
\hline 5000 & 16,23 & 0,1993 \\
\hline 6000 & 17,55 & 0,2286 \\
\hline
\end{tabular}

Tabel 2. Hasil Pengujian Pemakaian Jet Main Modifikasi (2,8 mm)

\begin{tabular}{|c|c|c|}
\hline Putaran mesin (rpm) & Torsi (NM) & $\begin{array}{c}\text { Konsumsi bahan bakar/waktu } \\
(\mathrm{ml} / \mathrm{s})\end{array}$ \\
\hline 2000 & 16,19 & 0,1281 \\
\hline 2500 & 16,24 & 0,1354 \\
\hline 3000 & 16,31 & 0,1689 \\
\hline 4000 & 16,48 & 0,1986 \\
\hline 5000 & 16,62 & 0,2013 \\
\hline 6000 & 17,94 & 0,2313 \\
\hline
\end{tabular}

Dalam proses pengujian, waktu yang dihabiskan saat kondisi Jet Main Standard adalah $\pm 3,5$ menit. Saat kondisi Jet Main $2,8 \mathrm{~mm}$ adalah $\pm 3,8$ menit.

\section{B. PEMBAHASAN}

Dari data hasil pengujian maka dapat dibuat grafik hubungan antara:

\section{1) Torsi (Nm) dengan Putaran Mesin (rpm)}

Dari pengujian mesin yang telah dilakukan dengan variasi alat Jet Main 2,5 mm, Jet Main 2,8 $\mathrm{mm}$ dan putaran mesin yang berbeda didapatkan data torsi sebagai berikut:

Tabel 3. Hasil Analisis Torsi (Nm)

\begin{tabular}{|c|c|c|}
\hline \multirow{2}{*}{$\begin{array}{c}\text { Putaran mesin } \\
(\mathrm{rpm})\end{array}$} & \multicolumn{2}{|c|}{ Torsi yang dihasilkan (Nm) } \\
\cline { 2 - 3 } & 1 & 2 \\
\hline 2000 & 15,80 & 16,19 \\
\hline 2500 & 15,86 & 16,24 \\
\hline 3000 & 15,92 & 16,31 \\
\hline 4000 & 16,09 & 16,48 \\
\hline 5000 & 16,23 & 16,62 \\
\hline 6000 & 17,55 & 17,94 \\
\hline
\end{tabular}

Keterangan dari tabel 3

1= Keadaan Jet Main 2,5 $\mathrm{mm}$ atau standard

2= Keadaan Jet Main 2,8 $\mathrm{mm}$ atau modifikasi

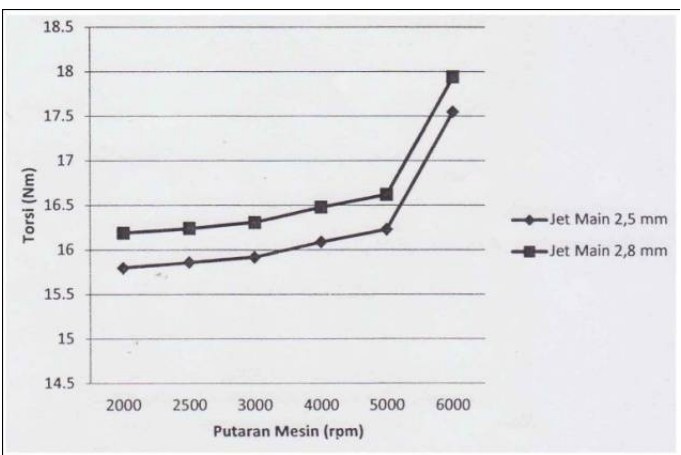

Gambar 6. Grafik Torsi (Nm) vs Putaran Mesin (rpm)

Torsi yang diukur dalam pengujian ini adalah torsi setelah melalui kopling manual, gigi transmisi dan hubungan poros dengan kopling dan gigi transmisi. Gambar 6 menunjukkan perbandingan antara putaran mesin dengan torsi yang dihasilkan dari data hasil pengujian dengan keadaan Jet Main Standard (2,5 mm) dan Jet Main 2,8 mm.

Karburator berfungsi mencampur dan mengkabutkan bahan bakar. Dengan adanya pengkabutan itu seiring dengan pertambahan putaran, torsi juga bertambah. Naiknya torsi adanya proses pembakaran campuran bahan bakar yang dihasilkan karburator. Bahwa untuk Jet Main Standard dan Jet Main yang dimodifikasi yaitu jumlah campuran bahan bakar menjadi lebih banyak pada Jet Main 2,8 $\mathrm{mm}$ atau yang dimodifikasi.

Dari Gambar 6 torsi yang dihasilkan dari Jet Main 2,8 $\mathrm{mm}$ yang modifikasi menghasilkan torsi sebesar 17,94 $\mathrm{Nm}$. Menghasilkan kenaikan 2,2 \% dari Jet Main yang Standard. Jet Main 2,5 mm yang standard menghasilkan torsi sebesar $17,55 \mathrm{Nm}$.

\section{2) Daya (kW) dengan Torsi (Nm)}

$$
\begin{aligned}
& \mathrm{P}=(\mathrm{T} \times \omega) \\
& \mathrm{P}=2 \pi \mathrm{N} \times \mathrm{T} \times 10^{-4} \quad \omega=2 \pi \mathrm{N} \\
& \mathrm{T}=\text { Torsi }(\mathrm{Nm}) \\
& \mathrm{P}=\text { Daya }(\mathrm{kW})
\end{aligned}
$$


$\mathrm{N}=$ Putaran kerja poros engkol (rev/s)

a. Keadaan Jet Main 2,5 $\mathrm{mm}$ atau standard. Pada putaran mesin 2000 rpm didapat hasil torsi $15,80 \mathrm{Nm}$. Maka daya yang dihasilkan:

$\mathrm{P}=2 \pi \mathrm{N} \times \mathrm{T} \times 10^{-4}$

$$
\begin{aligned}
& \mathrm{P}=2 \times 3,14 \times 200 / 60 \times 15,80 \times \\
& 10^{-4}(\mathrm{~kW}) \\
& \mathrm{P}=3,3074 \mathrm{~kW}
\end{aligned}
$$

b. Keadaan Jet Main 2,8 $\mathrm{mm}$ atau modifikasi. Pada putaran mesin 2000 rpm didapat hasil torsi $16,19 \mathrm{Nm}$. Maka daya yang dihasilkan:

$$
\mathrm{P}=2 \pi \mathrm{N} \times \mathrm{T} \times 10-4
$$$$
\mathrm{P}=2 \times 3,14 \times 200 / 60 \times 16,19 \times 10^{-4}
$$
$(\mathrm{kW})$

$\mathrm{P}=3,3891 \mathrm{~kW}$

Perhitungan yang sama dilakukan pada Jet Main yang berbeda, sehingga didapatkan hasil data sebagai berikut:

Tabel 4. Hasil Analisis Daya $(\mathrm{kW})$

\begin{tabular}{|c|c|c|}
\hline \multirow{2}{*}{$\begin{array}{c}\text { Putaran mesin } \\
(\mathrm{rpm})\end{array}$} & \multicolumn{2}{|c|}{ Daya yang dihasilkan (kW) } \\
\cline { 2 - 3 } & 1 & 2 \\
\hline 2000 & 3,3074 & 3,3891 \\
\hline 2500 & 3,3200 & 3,3995 \\
\hline 3000 & 3,3325 & 3,4142 \\
\hline 4000 & 3,3681 & 3,4498 \\
\hline 5000 & 3,3974 & 3,4791 \\
\hline 6000 & 3,6738 & 3,7554 \\
\hline
\end{tabular}

Keterangan dan tabel 4

1 = Keadaan Jet Main 2,5 $\mathrm{mm}$ atau standard

2 = Keadaan Jet Main 2,8 $\mathrm{mm}$ atau modifikasi

Pengujian ini dilakukan pada vaniabel keadaan Jet Main 2,5 $\mathrm{mm}$ atau standard, Jet Main 2,8 $\mathrm{mm}$ atau modifikasi dan dalam variabel putaran yang sama (2000 rpm - $6000 \mathrm{rpm}$ ). Hubungan antara daya $(\mathrm{kW})$ dan torsi $(\mathrm{Nm})$ dapat dilihat pada Gambar grafik di bawah ini:

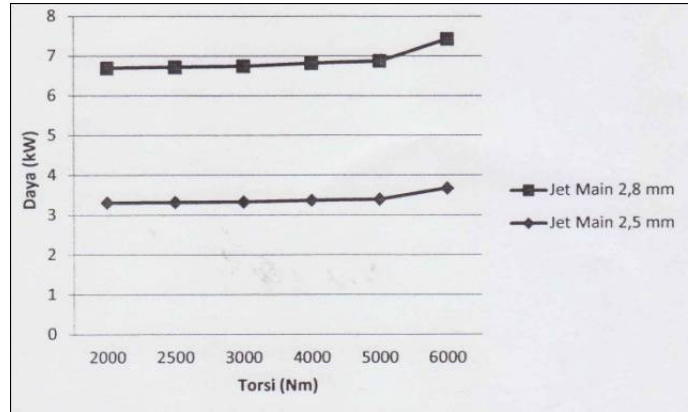

Gambar 7. Daya (kW) vs Torsi (Nm)

Pada Gambar 7. Daya poros merupakan hasil kali antara torsi dan kecepatan sudutnya, sehingga daya poros sangat tergantung dari nilai torsi yang dihasilkan oleh motor bakar tersebut. Pada pengujian ini daya yang dihasilkan pada keadaan Jet Main 2,8 mm relatif lebih tinggi dibandingkan dengan Jet Main 2,5 $\mathrm{mm}$ atau standard, semakin besar nilai torsi semakin besar pula daya yang dihasilkan.

Daya maksimum dari keadaan Jet Main 2,8 $\mathrm{mm}$ atau modifikasi sebesar $3,7554 \mathrm{~kW}$ pada putaran mesin $6000 \mathrm{rpm}$, menghasilkan kenaikan daya 2,2\% dari Jet Main 2,5 mm. Pada Jet Main 2,5 mm atau standard menghasilkan daya maksimum 3,6738 kW pada putaran $6000 \mathrm{rpm}$.

Daya rata-rata yang dihasilkan dengan keadaan Jet Main 2,5 $\mathrm{mm}$ atau standard sebesar 3,3998 kW. Pada Jet Main 2,8 mm atau modifikasi daya rata-rata yang dihasilkan sebesar 3,4811 kW, menghasilkan kenaikan daya 2,4\%.

\section{3) Laju Konsumsi Bahan Bakar (mf) dengan Putaran (rpm)}

$\mathrm{mf}=\frac{1}{\mathrm{t}} \times \rho \mathrm{bb}$

$\mathrm{mf}=$ Laju konsumsi bahan bakar (gr/detik)

$1=$ Waktu putaran mesin (detik)

$\mathrm{t}=$ Waktu konsumsi bahan bakar per $2 \mathrm{~cm}^{3}$ $\rho b b=$ Massa jenis bahan bakar $\left(\mathrm{gr} / \mathrm{cm}^{3}\right)$ (jurnal pertamina, 1998, 34, www.pertamina.com)

a. Keadaan Jet Main 2,5 $\mathrm{mm}$ atau standard

Pada putaran 2000 rpm dengan torsi $15,80 \mathrm{Nm}$ dan waktu 22,35 detik menghabiskan $2 \mathrm{~cm}^{3}$

$$
\begin{gathered}
\mathrm{mf}=\frac{1}{\mathrm{t}} \times \rho \mathrm{bb} \\
\mathrm{mf}=\frac{2\left(\mathrm{~cm}^{3}\right)}{22,35(\mathrm{~s})} \times 0,73 \mathrm{gr} / \text { detik } \\
\mathrm{mf}=0,0670 \mathrm{gr} / \text { detik }
\end{gathered}
$$


Jurnal ENGINE Vol.1 No.1, Mei 2017, pp 11-19 e-ISSN: 2579-7433

Pembakaran sempurna adalah dimana senyawa hidrokarbon (bahan bakar fosil) membentuk karbondioksida dan uap air.

Untuk perbandingan data hasil pengujiannya dapat dilihat pada tabel dibawah ini:

Tabel 5. Hasil Analisis mf

\begin{tabular}{|c|c|c|}
\hline \multirow{2}{*}{$\begin{array}{c}\text { Putaran mesin } \\
(\mathrm{rpm})\end{array}$} & \multicolumn{2}{|c|}{$\mathrm{mf}(\mathrm{gr} /$ detik) } \\
\cline { 2 - 3 } & 1 & 2 \\
\hline 2000 & 0,0653 & 0,0670 \\
\hline 2500 & 0,0747 & 0,0794 \\
\hline 3000 & 0,0821 & 0,0872 \\
\hline 4000 & 0,0958 & 0,0988 \\
\hline 5000 & 0,1354 & 0,1386 \\
\hline 6000 & 0,1451 & 0,1489 \\
\hline
\end{tabular}

Keterangan dan tabel 5

1= Keadaan Jet Main 2,5 $\mathrm{mm}$ atau standard

2= Keadaan Jet Main 2,8 $\mathrm{mm}$ atau modifikasi

Pengujian ini dilakukan pada vaniabel keadaan Jet Main 2,5 $\mathrm{mm}$ atau standard, Jet Main 2,8 $\mathrm{mm}$ atau modifikasi dan dalam variabel putaran yang sama (2000 rpm - $6000 \mathrm{rpm})$. Hubungan antara laju konsumsi bahan bakar (mf) dan putaran (rpm) dapat dilihat pada gambar grafik dibawah ini:

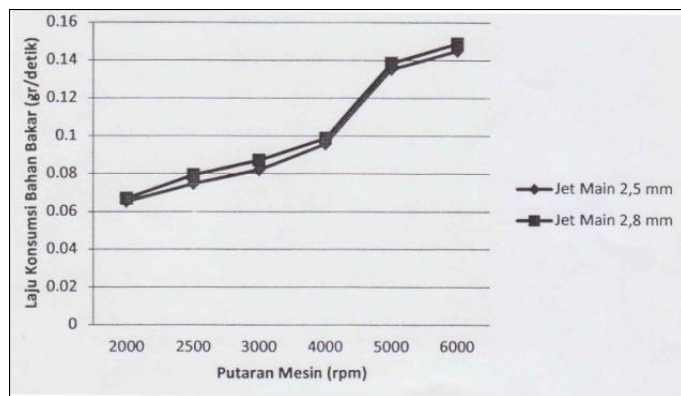

Gambar 8. Grafik Laju Konsumsi Bahan Bakar (mf) vs Putaran Mesin (rpm)

Pada gambar 8 terlihat bahwasanya untuk Jet Main modifikasi laju konsumsi bahan bakar semakin meningkat seiring dengan kenaikan putaran mesin. Laju konsumsi bahan bakar yaitu besarnya jumlah masaa bahan bakar yang dibutuhkan tiap satuan waktu. Dalam setiap pembakaran dibutuhkan campuran yang homogen, apabila konsumsi bahan bakar meningkat, maka bahan bakar yang dibutuhkan untuk proses pembakaran pun ikut meningkat. Besar kecilnya laju

konsumsi bahan bakar tergantung pada nilai putaran mesin, semakin tinggi putaran mesin yang dihasilkan maka semakin besar pula bahan bakar yang dibutuhkan untuk proses pembakaran.

4) Konsumsi Bahan Bakar (sfe) dengan Putaran Mesin (rpm)

$$
\mathrm{sfc}=\frac{\mathrm{mf}}{\mathrm{P}}
$$

sfc $=$ Konsumsi bahan bakar spesifik (kg/HP jam) $\mathrm{P}=$ Daya $(\mathrm{kW})$ $\mathrm{mf}=$ Laju konsumsi bahan bakar (gr/detik)

a. Keadaan Jet Main 2,5 $\mathrm{mm}$ atau standard

Pada putaran 2000 rpm dengan torsi $15,80 \mathrm{Nm}$ dan waktu 22,35 detik menghabiskan $2 \mathrm{~cm}^{3}$.

$$
\begin{aligned}
\mathrm{sfc} & =\frac{\mathrm{mf}}{\mathrm{P}} \\
\mathrm{sfc} & =\frac{0,0653}{3,3074} \\
\mathrm{sfc} & =0,0197 \mathrm{~kg} / \mathrm{HP} \text { jam }
\end{aligned}
$$

b. Keadaan Jet Main 2,8 $\mathrm{mm}$ atau modifikasi

Pada putaran 2000 rpm dengan torsi 16,19 Nm dan waktu 21,76 detik menghabiskan $2 \mathrm{~cm}^{3}$ :

$$
\begin{aligned}
\mathrm{sfc} & =\frac{\mathrm{mf}}{\mathrm{P}} \\
\mathrm{sfc} & =\frac{0,0670}{3,3891} \\
\mathrm{sfc} & =0,0197 \mathrm{~kg} / \mathrm{HP} \text { jam }
\end{aligned}
$$

Semakin rendah nilai sfc maka semakin rendah pula konsumsi bahan bakar yang digunakan.Untuk perbandingan data hasil pengujian dapat dilihat pada tabel dibawah ini :

Tabel 6 Hasil Analisis sfc

\begin{tabular}{|c|c|c|}
\hline \multirow{2}{*}{$\begin{array}{c}\text { Putaran Mesin } \\
(\mathrm{rpm})\end{array}$} & \multicolumn{2}{|c|}{ sfc yang dihasilkan $(\mathrm{kg} / \mathrm{HP}$ jam) } \\
\cline { 2 - 3 } & 1 & 2 \\
\hline 2000 & 0,0197 & 0,0197 \\
\hline 2500 & 0,0225 & 0,0233 \\
\hline 3000 & 0,0246 & 0,0255 \\
\hline 4000 & 0,0284 & 0,0286 \\
\hline 5000 & 0,0398 & 0,0398 \\
\hline 6000 & 0,0395 & 0,0396 \\
\hline
\end{tabular}

Keterangan dari tabel 6

1 = Keadaan Jet Main 2,5 $\mathrm{mm}$ atau standard 
Jurnal ENGINE Vol.1 No.1, Mei 2017, pp 11-19

e-ISSN: 2579-7433

$2=$ Keadaan Jet Main 2,8 $\mathrm{mm}$ atau modifikasi

Pengujian ini dilakukan pada variabel keadaan Jet Main 2,5 $\mathrm{mm}$ atau standard, Jet Main 2,8 $\mathrm{mm}$ atau modifikasi dan dalam variabel putaran yang sama (2000 rpm - $6000 \mathrm{rpm}$ ). Hubungan antara konsumsi bahan bakar spesifik (sfc) dan putaran mesin (rpm) dapat dilihat pada Gambar grafik di bawah ini:

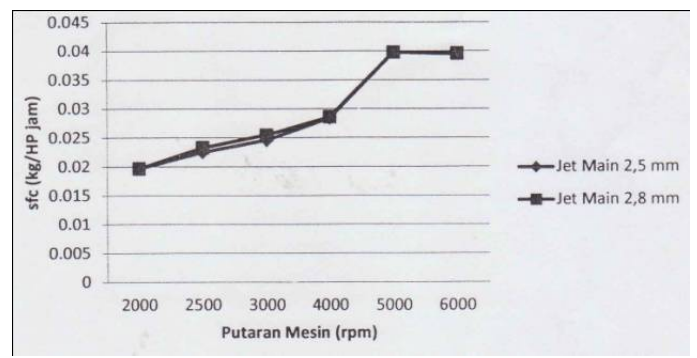

Gambar 9 Grafik Konsumsi Bahan Bakar Spesifik (sfc) vs Putaran Mesin (rpm).

Konsumsi bahan bakar spesifik (sfc) merupakan hasil bagi antara konsumsi bahan bakar dengan daya poros. Pada grafik terlihat bahwa konsumsi bahan bakar spesifik untuk Jet Main modifikasi akan semakin naik seiring dengan kenaikan putaran mesin. Konsumsi bahan bakar spesifik pada keadaan Jet Main 2,5 $\mathrm{mm}$ atau standard, sfc rata-rata yang dihasilkan sebesar 0,0291 kg/HP jam. Pada Jet Main 2,8 $\mathrm{mm}$ atau modifikasi sfc ratarata sebesar $0,0294 \mathrm{~kg} / \mathrm{HP}$ jam menghasilkan kenaikan sfc $1 \%$.

\section{5) Kalor pemakaian bahan bakar (Qi) dengan Daya $(\mathrm{kW})$}

$$
\mathrm{Qi}=\frac{\mathrm{Ni}}{\eta \mathrm{i}}(\mathrm{hp})
$$

Qi $=$ Kalor input (Kcal)

$\mathrm{Ni}=$ Daya $(\mathrm{kW})$

$\eta \mathrm{i}=$ Efisiensi Indikator $=0,40(\eta \mathrm{i}=0,35-$ 0,45. Diambil harga menengah dengan melihat kondisi daya yang dihasilkan)

a. Keadaan Jet Main 2,5 $\mathrm{mm}$ atau standard pada putaran $2000 \mathrm{rpm}$ 
Jurnal ENGINE Vol.1 No.1, Mei 2017, pp 11-19

e-ISSN: 2579-7433

Pada Gambar 10 terlihat bahwa untuk Jet Main modifikasi kalor input mengalami kenaikan pada setiap variabel pengujian namun tidak sampai mengalami over heat, sehingga kalor yang relative tinggi ini sebagian dari kalor input digunakan untuk melakukan kerja oleh working substance dari mesin, yaitu material dalam mesin yang secara aktual melakukan kerja (campuran bensin dan udara dalam mesin).

6) Efisiensi Bahan Bakar (\%) dengan Daya $(k W)$

$$
\eta \mathrm{f}=\frac{1}{\mathrm{sfc} \cdot \mathrm{Q}_{\mathrm{HV}}} 100 \%
$$

QHv Premium $45 \mathrm{MJ} / \mathrm{Kg}$

a. Keadaan Jet Main 2,5 $\mathrm{mm}$ atau standard pada putaran $2000 \mathrm{rpm}$

$$
\begin{aligned}
& \eta \mathrm{f}=\frac{1}{(0,0197 \times 45)} 100 \% \\
& \eta \mathrm{f}=22,8 \%
\end{aligned}
$$

b. Keadaan Jet Main 2,8 $\mathrm{mm}$ atau modifikasi pada putaran $2000 \mathrm{rpm}$

$$
\begin{aligned}
& \eta f=\frac{1}{(0,0197 \times 45)} 100 \% \\
& \eta f=22,8 \%
\end{aligned}
$$

Perhitungan yang sama dilakukan pada variasi putaran yang berbeda, sehingga didapatkan hasil data sebagai berikut:

Tabel 8 Hasil Analisis Efisiensi Bahan Bakar

\begin{tabular}{|c|c|c|}
\hline \multirow{2}{*}{$\begin{array}{c}\text { Putaran Mesin } \\
(\mathrm{rpm})\end{array}$} & \multicolumn{2}{|c|}{ Efisiensi Bahan Bakar (\%) } \\
\cline { 2 - 3 } & 1 & 2 \\
\hline 2000 & 22,8 & 22,8 \\
\hline 2500 & 20 & 19,3 \\
\hline 3000 & 18,3 & 17,6 \\
\hline 4000 & 15,8 & 15,7 \\
\hline 5000 & 11,3 & 11,3 \\
\hline 6000 & 11,4 & 11,4 \\
\hline
\end{tabular}

Keterangan dari Tabel 8

1 = Keadaan Jet Main 2,5 $\mathrm{mm}$ atau standard

2 = Keadaan Jet Main 2,8 $\mathrm{mm}$ atau modifikasi

Pengujian ini dilakukan pada variabel keadaan Jet Main 2,5 $\mathrm{mm}$ atau standard, Jet Main 2,8 $\mathrm{mm}$ atau modifikasi dan dalam variabel putaran yang sama (2000 rpm - $6000 \mathrm{rpm})$. Hubungan antara efisiensi (\%) dan daya $(\mathrm{kW})$ dapat dilihat pada Gambar grafik di bawah ini:

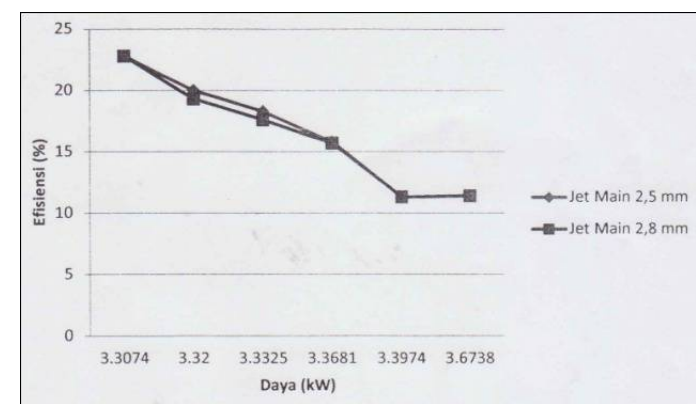

Gambar 11 Grafik Efisiensi (\%) dan Daya $(\mathrm{kW})$

Efisiensi bahan bakar (\%) menunjukkan besarnya perbandingan antara daya yang dihasilkan oleh suatu mesin dalam satu siklus terhadap jumlah energi bahan bakar yang disuplai persiklus yang dapat dilepaskan dalam suatu proses pembakaran. Oleh karena itu jika harga konsumsi bahan bakarnya (sfc) semakin besar maka harga efisiensinya akan semakin menurun. Semakin banyak konsumsi bahan bakar yang dibutuhkan dalam proses pembakaran, maka semakin banyak bahan bakar yang digunakan atau dibutuhkan.

\section{KESIMPULAN}

Dari hasil penelitian pengaruh perubahan diameter lubang saluran keluar Jet Main pada karburator terhadap kinerja mesin bensin 4 langkah satu silinder pada sepeda motor dapat disimpulkan sebagai berikut :

\section{Torsi $(\mathbf{N m})$}

a. Alat Jet Main 2,5 $\mathrm{mm}$ atau standard menghasilkan torsi sebesar 17,55 Nm

b. Alat Jet Main $2,8 \mathrm{~mm}$ atau modifikasimenghasilkan torsi 
Jurnal ENGINE Vol.1 No.1, Mei 2017, pp 11-19

e-ISSN: 2579-7433

sebesar $17,94 \mathrm{Nm}$ terjadi kenaikan torsi sebesar 2,2\%.

\section{Daya $(\mathbf{k W})$}

a. Alat Jet Main 2,5 $\mathrm{mm}$ atau standard menghasilkan daya maksimum sebesar $3,6738 \mathrm{~kW}$ dan daya rata-rata sebesar $3,399 \mathrm{~kW}$.

b. Alat Jet Main $2,8 \mathrm{~mm}$ atau modifikasimenghasilkan daya maksimum sebesar $3,7554 \mathrm{~kW}$ terjadi kenaikan daya rata-rata sebesar 2,4\%.

3. Laju Konsumsi bahan bakar (mf)

a. Alat Jet Main 2,5 $\mathrm{mm}$ atau standard menghasilkan $\mathrm{mf}$ rata-rata sebesar 0,0794 gr/detik.

b. Alat Jet Main $2,8 \mathrm{~mm}$ atau modifikasimenghasilkan $\mathrm{mf}$ rata-rata sebesar 0,1033 gr/detik.

\section{Konsumsi bahan bakar spesifik} (sfc)

a. Alat Jet Main 2,5 $\mathrm{mm}$ atau standard menghasilkan sfc rata-rata sebesar 0,0291 $\mathrm{kg} / \mathrm{HP} . \mathrm{jam}$.

b. Alat Jet Main 2,8 $\mathrm{mm}$ atau modifikasimenghasilkan sfc rata-rata sebesar 0,0294 $\mathrm{kg} / \mathrm{HP}$.jam.

Konsumsi bahan bakar spesifik (sfc) merupakan hasil bagi antara konsumsi bahan bakar dengan daya poros.

\section{Kalor pemakaian bahan bakar} (Qi)

a. Alat Jet Main 2,5 $\mathrm{mm}$ atau standard menghasilkan Qi rata-rata sebesar 1,4929 Kcal/detik.

b. Alat Jet Main $2,8 \mathrm{~mm}$ atau modifikasimenghasilkan Qi rata-rata sebesar 1,5286 Kcal/detik.

\section{Efisiensi bahan bakar (\%)}

a. Alat Jet Main 2,5 $\mathrm{mm}$ atau standard menghasilkan efisiensi rata-rata sebesar $16,6 \%$.

b. Alat Jet Main 2,8 $\mathrm{mm}$ atau modifikasimenghasilkan efisiensi rata-rata sebesar 16,3 $\%$.

\section{DAFTAR PUSTAKA}

Arends, BPM \& Berenscot H. 1980, Motor Bensin, Alih Bahasa: Umar Sukrisno, Penerbit: Erlangga, Jakarta.

Arismunandar, W. 2002, Penggerak Mula Motor Bakar Torak, ITB Bandung.

Cengel, A. Yunus \& Boles, Michael A. 1994, Thermodynamics An Engineering Approach, Mc Graw-Hill Book Inc., New York.

Daryanto, 2003 "Motor Bensin pada Mobil”, Yrama Widya, bandung.

Ferguson, Cohn R. 1986, Internal Combustion Engine - Applied Thermosciences, Purdue University.

Heywood, LB 1988, Internal Combustion Engine Fundamentals, Singapore: Mcgraw-Hill Book Co.

Maleev, V. L. 1973, International Critical Tables, vol. 1, Mc Graw-Hill Book Inc., New York.

Obert, F.E. 1973, Internal Combustion Engines and Air Pollution, $3^{\text {rd }}$ Edition New York: Harper \& Row Publishing.

Timing, 2006. Manifold Powerman. Motor Plus Edisi 326.

Edwin, 2004. Manifold Powerman. Komoditas Honda Tiger Indonesia. 